https://helda.helsinki.fi

\title{
On Yearbooks
}

\section{Klabbers, Jan}

T.M.C. Asser Press cop.

2021

Klabbers , J 2021, On Yearbooks . in O Spijkers , W G Werner \& R A Wessel (eds), Yearbook of International Law 2019. Netherlands Yearbook of International Law, vol. 50 ,

T.M.C. Asser Press cop. , The Hague , pp. 45-57 . https://doi.org/10.1007/978-94-6265-403-7_5

http://hdl.handle.net/10138/337060

https://doi.org/10.1007/978-94-6265-403-7_5

other

acceptedVersion

Downloaded from Helda, University of Helsinki institutional repository.

This is an electronic reprint of the original article.

This reprint may differ from the original in pagination and typographic detail.

Please cite the original version. 
On Yearbooks

Jan Klabbers ${ }^{1}$

I. Introduction

I grew up, academically, on yearbooks of international law - they formed a notable part of my education. As an undergraduate student with a serious interest in international law, and later when writing my doctoral dissertation, yearbooks were among the sources of information, knowledge and understanding I keenly pursued. Partly this was because one just had to make do with whatever one could find: Al Gore (or whoever) had not yet invented or popularized the internet, so all I had available to me was whatever subscriptions were held by the law library of the University of Amsterdam and had arrived as physical copies. Among these were a variety of yearbooks.

But there was more to it than just the old adage that "beggars can't be choosers". There was something about the yearbooks, or at least some of them, that made them seem valuable beyond being merely repositories of academic articles of varying quality. Somehow the yearbooks seemed to speak for entire communities, in ways that rarely apply to journals, let alone research monographs. ${ }^{2}$ Additionally, and perhaps more obviously, the yearbooks were sources of information concerning the state practice of their respective states, and by selecting materials from state practice and judicial practice they taught me about what is legally relevant and what is legally not so relevant, or at least what some considered to be relevant or not so relevant. Reading yearbooks amounted, in a sense, to reading the language of international law as it is actually used, outside the context of research monographs, learned articles, and textbooks. By reproducing practice, the yearbooks provided a glimpse into that very practice, and helped me develop my skills as a doctrinal international lawyer.

\section{Ranking}

\footnotetext{
${ }^{1}$ Professor of International Law, University of Helsinki.

${ }^{2}$ Although occasionally a textbook-like collection can approach something similar, almost (but not quite) in the manner of a 1960s East-German Autorenkollektiv. What I have in mind is Natalie Horbach, René Lefeber and Olivier Ribbelink (eds.), Handboek international recht (The Hague: T.M.C. Asser Press, 2007), offering a collection of Dutch authors writing in Dutch on international law, emphasizing issues that resonate with the Dutch, by and large reflecting Dutch pre-occupations. It differs from the Autorenkollektiv though in that individual chapters are individually signed. On a lesser level of cultural homogeneity, something similar may apply to Malcolm Evans (ed.), International Law, $5^{\text {th }}$ edn (Oxford University Press, 2018), which by and large offers a British perspective but also uses authors born and educated outside the UK, and some who have no particular affiliation with the UK, this coming closer to the cosmopolitanism underlying R.St.J. MacDonald and D.M. Johnstone, The Structure and Process of International Law: Essays in Legal Philosophy Doctrine and Theory (The Hague: Martinus Nijhoff, 1983), encompassing authors from all over the globe or, likewise, Max Sörensen (ed.), Manual of Public international Law (New York: St. Martin's Press, 1968). For the record, those cosmopolitan enterprises, for all their cosmopolitanism, comprised exclusively male authors.
} 
Let's first get one issue out of the way: yearbooks are not usually known for the quality of the articles they contain. Obviously, as a general statement this is far too blunt and over-the-top, and especially in the days when yearbooks were the main outlet for academic international lawyers (whether within their state or more broadly), they could contain excellent work. Imagine the British Yearbook without the contributions by Sir Hersch Lauterpacht, Lord McNair, or Sir Gerald Fitzmaurice, and the point will become clear at once.

Yearbooks moreover have a tradition, and still have the possibility, of publishing longer articles. The wonderful work by Fitzmaurice on the ICJ case-law in the British Yearbook was followed, decades later, by equally wonderful work by Thirlway: lengthy and systematic analyses of the case-law of the International Court of Justice, of a length and depth that would have rendered these pieces unlikely to be published elsewhere. The space offered by the British Yearbook, moreover, also informed the structure of the analysis: the way these articles were composed would not have been possible in even a serial format of shorter pieces. It was the format of the yearbook article which allowed for discussion in minute detail, although it remains uncertain perhaps whether this was facilitated by the venue being a yearbook, or by the relatively absence of the cookie-cutter model of peer reviewed articles. D'Aspremont surely had a point when observing (on a blog, mind you) that he himself, when writing with peer reviewed journals in mind, sticks to a fairly conventional way of writing and thinking. ${ }^{3}$

And sometimes yearbooks get lucky, in that they stumble on a piece, usually someone's public lecture, which captures the Zeitgeist, which captures something of relevance for that particular moment. The best example may well be Sir Robert Jennings' 'What is International Law and How do we Tell it when We See It?', published in the Swiss Yearbook of International Law and probably the most-cited article ever to have been published in that yearbook - and probably by a considerable margin at that. ${ }^{4}$

But by and large, seminal articles tend to get published in journals rather than yearbooks, as is reflected in national rankings of periodicals. The venerable British Yearbook, e.g., is in the Finnish system $^{5}$ given the grade 1 (basic), as are some other yearbooks (the Canadian Yearbook of International Law, the Annuaire Francais du Droit International, and a handful of others). Therewith, they are ranked below a journal such as the Leiden Journal of International Law (ranked in category 2, leading journals) or the European Journal of International Law (category 3, top journals). The classifications themselves, of course, are questionable: it is nigh-on impossible to sense the difference between "leading" and "top", but similar problems afflict other comparative schemes: funding agencies may differentiate between "excellent" and "outstanding"

\footnotetext{
${ }^{3}$ https://www.ejiltalk.org/destination-the-wasteland-of-academic-overproduction-part-1/ (accessed 25 May 2020).

${ }^{4}$ Sir Robert Jennings, "What is International Law, and How Can We Tell It When We See It?", (1981) 37 Schweizerisches Jahrbuch für Internationales Recht, 59-88.

${ }^{5}$ Known as Julkaisufoorumi (Publication Forum), or JuFo in abbreviated form. When journals are sometimes listed as 0 , the explanation is that their quality has not been assessed, mostly, one may assume, because it is not a popular venue for Finnish scholarship. The JuFo rankings are used not just to assess the level of publications, but also of such activities as being engaged in peer review: reviewing a submission for the European Journal is somehow more "valuable" than reviewing an article for the British Yearbook.
} 
scholars in ways that baffle the rest of us; and to be considered a "very good" scholar is, in these contexts, rather insulting.

That the British Yearbook ranks below the Leiden Journal and the European Journal is, on current form, perhaps not all that surprising. What is more surprising is that it also ranks below the Nordic Journal (category 2, leading) and even the Finnish law journal Lakimies ${ }^{6}$ (also 2), despite the circumstance that it is considerably easier to get published in Lakimies than in the British Yearbook - although, in the Finnish language and amongst Finnish lawyers, Lakimies is indeed by far the leading law journal. ${ }^{7}$ This suggests two things. First, it suggests that those rankings are eminently open to manipulation: if Lakimies would not be given a high rank (higher than arguably is merited on substantive grounds or in light of the statistical probability of getting a submission accepted ${ }^{8}$ ), Finnish domestic lawyers would rarely be in a position to publish in a journal of such ranking, unless they would look to publish internationally. This, in turn, would make the domestic lawyers look bad when compared to their international law colleagues, and would also make them look bad in comparison to Finland's social scientists. Ex hypothesi, it cannot be the case that lawyers are worse scholars than others in the humanities or social sciences, but since a purely qualitybased ranking of journals would suggest as much, the ranking has to be interfered with - there is no other option once the idea of ranking publications has been accepted, and given the largely domestic audience for most academic work in fields such as consumer protection law or urban planning law. Second though, and more to the point for present purposes, the British Yearbook's score reflects the relatively low regard in which yearbooks are held these days which, in turn, will mean that they become less attractive as venues for publication.

Some classic pieces have been published in yearbooks. On the topic of self-contained regimes, e.g., which pre-occupied international lawyers for a while before they re-christened it "fragmentation", no bibliography is complete with reference to Bruno Simma's contribution to the Netherlands Yearbook. ${ }^{9}$ Likewise, on the evergreen issue of treaty conflict, Manfred Zuleeg's piece in the 1977 German Yearbook is a compulsory reference. Both articles set the tone on their topic for quite some time to come and were thus highly influential. Both are also somewhat atypical: Simma's was written for a special issue for the Netherlands Yearbook, a concept increasingly embraced by the Netherlands Yearbook, obscuring the differences between yearbooks and edited volumes. Zuleeg's was somewhat atypical for being published in German, despite English being the main publishing language (already then) of the German Yearbook. ${ }^{10}$ Curiously, one suspects that if both pieces were now offered for peer review, they might not survive the process. That is no slight

\footnotetext{
${ }^{6}$ The word means, literally, Lawyer. Lakimies is published 8 times a year on behalf of the national lawyers' association, and a typical issue comprises four to six articles of regular length, two or three shorter contributions, and some book reviews. The tenor is highly doctrinal and no field of law is excluded. That said, Finland's international lawyers rarely publish in Lakimies, probably because they have other venues at their disposal.

${ }^{7}$ There is not much competition, to be honest: the main competitor is a journal called Defensor Legis, which is more closely associated with legal practice, publishing case notes and short and snappy overview pieces, but little that involves the type of reflection usually associated with academic work.

${ }^{8}$ Lakimies has a page budget of some 1200 pages per year, divided over eight issues. The pool of authors being able and willing to write academic legal texts in Finnish (population 5.5 million, four law schools) is relatively small.

${ }^{9}$ Bruno Simma, 'Self-Contained Regimes', (1985) 16 Netherlands Yearbook of International Law, 112-136.

${ }^{10}$ Manfred Zuleeg, 'Vertragskonkurrenz im Völkerrecht. Teil 1: Verträge zwischen souveränen Staaten', (1977) 20 German Yearbook of International Law, 246-276.
} 
on the articles - both are classics, and deservedly so. But Simma's makes most sense in the context of a special issue, with several related pieces being published, while Zuleeg would nowadays face a language barrier. But this says more about peer review practices which, in law and the humanities (and qualitative social sciences) are hopelessly overrated to begin with.

\section{Ambivalence}

Yearbooks are curiously ambivalent products, and are ambivalent typically in two ways. First, as intimated above, they are often produced by and on behalf of a particular national international law community and this, by default, must cover not just the academics but also those representing that state in matters related to international law: foreign office lawyers, perhaps also those nationals working for international institutions or organs. To the extent that the yearbooks comment on national practices and positions, therefore, they represent a community commenting on itself. The yearbook is both subject and object, both author and lead character - and this alone makes the yearbook stand out.

There is, however, a pre-condition: this only applies to those yearbooks which actually somehow represent a national community, and not all yearbooks do this. The German Yearbook of International Law, e.g., has by and large remained a publication of the Walther Schücking Institute in Kiel. It sometimes has been very "German", but that is because some of the Kiel-based academics fit nicely in the post-war German tradition of international legal thinking - someone like Jost Delbrück, for instance. But the German Yearbook has intuitively never functioned as the unofficial mouthpiece of German international law. The role of mouthpiece was already taken by the much older and much more "established" Zeitschrift für ausländisches öffentliches Recht und Völkerrecht, and arguably, this role has diminished since the latter has started to refer to itself in English as the Heidelberg Journal of International Law. All of a sudden, the Zeitschrift was not from Germany, but from Heidelberg - a subtle difference, but a difference nonetheless. It also does not help to give a yearbook a specific focus: there is nothing wrong with the Max Planck Yearbook of United Nations Law, or the Yearbook of International Environmental Law, but these are essentially just serial publications on the parts of international law that can be associated with the United Nations (if that is what United Nations law represents) or aiming to cover international environmental law. But these are not yearbooks in quite the same way as the British, Netherlands, French, Canadian or Polish Yearbook of International Law - they do not construct and manifest a community of individuals based in a particular place in quite same way. ${ }^{11}$

That said, those communities themselves have also undergone considerable change. If the British Yearbook could still think of itself as British with an Australian (co-)editor in chief until a few years ago, its Britishness has become much more cosmopolitan (ironically perhaps, at a time when

\footnotetext{
${ }^{11}$ They might speak to a differently-oriented community, as one of the reviewers of this piece suggested (i.e. the community of UN lawyers, or the community of international environmental lawyers), but those would appear to be different kinds of communities. One can join these communities (indeed, several simultaneously) by taking a subscription, whereas one does not become a Dutch international lawyer by taking a subscription to the Netherlands Yearbook. And the idea of becoming part of the Dutch, Polish and French communities of international lawyers by subscribing to their respective yearbooks lacks credibility.
} 
Britain has turned inward) with an Israeli at the helm. Likewise, the particular Finnish-ness of the Finnish Yearbook was hardly highlighted when its editor in chief hailed from the Netherlands, something well understood in other jurisdictions: it would be unthinkable to have the Annuaire Francais run by someone from outside France, or at least from outside the Francophone community. ${ }^{12}$

Intriguingly however, and perhaps because it started much later, the Annuaire Francais is somehow less French, less community oriented, than the Revue Générale de Droit International Public, which was published as early as the 1890 s, and has always carried aspects of French state practice. The Annuaire Francais, by contrast, seems to have aimed at fostering not a national community but a cosmopolitan one, by providing overviews of international judicial practice, including the practice of international administrative tribunals. Moreover, it has arguably the most extensive book review section of any regular publication. If the Revue Générale caters to the domestic audience, the Annuaire Francais caters to a cosmopolitan audience. Whether it does so successfully is open for debate however - it probably does not help its cause by being exclusively Francophone. ${ }^{13}$ But nonetheless, the contrast is telling, unless one would hypothesize that the Annuaire Francais caters to the Francophone community, covering parts of Belgium and Switzerland and parts of Africa.

The second sense in which the yearbook is ambivalent is that it is unclear whether it should be seen as a book series, or as a journal. When I grew up (academically, again), the law library in Amsterdam treated the yearbooks as journals, and copies could be found alphabetically next to the bound volumes of journals, with the Netherlands Yearbook wedged in between the Netherlands International Law Review and the Nordic Journal of International Law. ${ }^{14}$ This is how I grew accustomed to yearbooks, and funny enough, this is still how I think they should be treated. Despite having been exposed to it for more than twenty years by now, I have been unable to internalize the Finnish practice of treating yearbooks as books, and thus physically locating them in the book sections of libraries. The differences are getting smaller of course now that most resources are electronically available: I can access articles from yearbooks on-line in much the same way as journal articles or chapters in edited volumes (the latter are books, of course, in my mental scheme). Plus, and inconsistently enough, for purposes of ranking publications, yearbooks are regarded by Finland's educational authorities (the aforementioned JuFo) as serial publications, i.e. in the same way as journals.

What makes yearbooks historically attractive is the additional consideration that in some jurisdictions, they were among the main publication outlets. The British may have had venerable law journals which would occasionally publish something on international law (the Law Quarterly Review, Cambridge Law Journal), but for about three decades the British Yearbook was the only

\footnotetext{
12 Then again, it is curiously reflective of Europe that two of the main figures in the history of the European Journal of International Law, Philip Alston and Joseph Weiler, both long-time editor in chief, are both non-Europeans by birth.

${ }^{13}$ It may be suspected that the cosmopolitan ambitions of the Annuaire Francais are premised on the perceived position of French as the lingua franca of the community of cosmopolitan international lawyers.

${ }^{14}$ This is actually not true: the Nordic Journal, for some mysterious reason, was kept not in the law library those days but in the main university library. I have forgotten though which journal was standing next to the Netherlands yearbook. Perhaps next to the Netherlands Yearbook was the Neue Juristische Wochenschrift.
} 
dedicated international law outlet, until the International and Comparative Law Quarterly was set up in the 1950s. And much the same applies to other jurisdictions, which are too small to sustain the three or four issues per year associated with most journals, but might just manage a single 'national' publication annually: the Finnish, or the Czech, or the Polish, or the three Baltic states combined producing the Baltic Yearbook of International Law. The Austrians have settled, pragmatically perhaps, on a hybrid solution: they publish what is effectively a yearbook, complete with large overviews of Austrian state practice, but it still carries the title of the journal which it replaced, the Austrian Review of International and European Law. ${ }^{15}$

\section{Community}

Quite possibly the best thing about yearbooks is that they sometimes offer excerpts from relevant state practice and judicial practice. The British Yearbook always has been exemplary, with extensive sections detailing Foreign Office practice (excerpts from memoranda, opinions on current incidents, et cetera) and a separate section on judicial practice. These would be compiled and edited by serious young scholars who en passant received a very fine traditional training in international law, which has no doubt helped them in their academic careers.

In addition to the regular section on judicial practice (outlining the judiciary's approach to matters of international law) and the equally regular section on diplomatic and parliamentary section (by and large representing the government's approach), the Netherlands Yearbook long had a third section, listing Dutch publications during the past year. This was highly entertaining and revealing for a while, suggesting that Professor Indolent had again managed not to publish anything the whole year, or that "op ed" pieces in small regional newspapers could also count among the publications of Professor Dryasdust. At some point this got a little stale, and that point was probably the point when the discipline became more professionalized, about 10-15 years ago, with people thinking of big-team research projects, preferably "paradigm shifting" and complete with "work packages" and "deliverables". It is open to serious questioning whether the quality of scholarship has improved as a result, but it is clear that in terms of quantity, the output has increased tremendously, so much so that a section on "Dutch publications during the previous year" would no longer be feasible.

One of the charms of that section (and an additional reason for its current impracticality) was also that it generated conversations on inclusion and exclusion, in much the same way as those conversations take place in other more or less organic communities. ${ }^{16} \mathrm{It}$ opened up vistas on who actually qualified as Dutch and, as with many governments, it would seem that the application of the standard for Dutch-ness was rather random and pragmatic. Upon moving to Finland, I still qualified for a while as Dutch, it seems, but at some point interest dried up and I disappeared from the statistics, despite me retaining my Dutch nationality (and, more importantly, despite me still

\footnotetext{
${ }^{15}$ It is effectively a yearbook in that it is published once a year, and combines academic articles with sections on Austrian state practice.

${ }^{16}$ The notion of organic community here is meant to differentiate such communities from communities one can join by purchasing their products, as in the "community of users of shampoo X".
} 
cheering for Dutch football), and notwithstanding the fact that I was publishing with some regularity. Conversely, the growth of big-time research projects brought a steady stream of people born outside the Netherlands to work at Dutch universities, either for PhD projects or as postdoctoral researchers, and thus (at least initially) for a limited period of time. So at what moment did Alessandra Arcuri become Dutch? Or Machiko Kanetake? And while traditionally, Dutchspeaking Belgians have held positions in Holland (Karel Wellens for a long time at Radboud University Nijmegen, or Cedric Ryngaert at Utrecht today), were they ever considered Dutch? Thus put, the annual section raised intriguing questions about both national and professional identity. The function of publishing excerpts from state practice and judicial practice is not limited to yearbooks. The venerable American Journal of International Law has done so since forever, as has the Zeitschrift. The Nordic Journal of International Law too tried to do so for a while, but stumbled on two problems, one inherent to the genre, and one specific to the Nordic Journal. The genre problem is that someone needs to actually compile and edit the work. Some institutional settings can accommodate this: with the British Yearbook being predominantly an Oxbridge product, often enough the work was delegated to junior scholars at Cambridge or Oxford. But the Nordic Journal lacked such an institutional background, even while physically located at the Raoul Wallenberg Institute in Lund - an ideal institutional setting for editorial continuity, one would think, but perhaps not that suitable for a general international law publication: the Institute's strength rests with human rights, and while there is some overlap, human rights lawyers and international lawyers move in different circles - with all this entails for identifying peers for reviewing purposes, for instance.

The specific problem for the Nordic Journal was (and is) that it marks collaboration between five Nordic states, and thus would have to cover the state practice of not just one, but five states. ${ }^{17}$ While these may overlap and sometimes in the name of efficiency are represented by one of them speaking on behalf of all of them, nonetheless the net result was that practical problems increased five-fold. Five authors first needed to be found and invited, and then needed to be chased just before the deadline; five authors whose texts needed to be edited; five authors whose work required some coordination. The pool, moreover, is small: the general international section the Finnish Foreign Ministry comprises a handful of individuals, and there is little reason to assume that the corresponding sections at the Foreign Offices of the other Nordic states are much bigger. The attempt was valiant, but proved short-lived, ${ }^{18}$ and yet, during its short lifespan made a valuable contribution: I can safely say that without the information thus collected and published, some of my own work would have been much more difficult to produce. ${ }^{19}$

There is, however, another issue with state practice digests which requires commenting, and it is this. It has become almost impossible for someone outside Foreign Office practice closely to follow

\footnotetext{
${ }^{17}$ The Nordic Journal is unique in that representatives of its member states' Foreign Ministries sit on the editorial board, together with a number of academics.

${ }^{18}$ Briefly, the Finnish Yearbook tried to take over, at least with respect to Finnish practice, but this too proved shortlived without some institutional backing.

${ }^{19}$ I wrote several pieces on treaty reservations for instance, which clearly benefitted from the easy availability of materials. See, e.g., Jan Klabbers, 'Accepting the Unacceptable? A New Nordic Approach to Reservations to Multilateral Treaties', (2000) 69 Nordic Journal of International Law, 179-193.
} 
whatever a state is doing in its foreign policy. There is, for one, too much going on, not just at the Foreign Office but also, and still increasingly so, at other departments. Defense ministries, Justice ministries, Transport ministries, Environment ministries, Culture ministries: they all have their own international activities these days and may all have to do with international law in one way or another, so much so that few people can keep track. ${ }^{20}$

In addition, a lot of this practice may be officially sold as non-legally binding and thus never even be reported, or not be reported where it would be expected. This is not a new phenomenon: already in his classic advocacy piece on the "informal international instrument", often referred to as Memorandum of Understanding, the late Tony Aust warned about problems of coordination and possible retrieval problems, ${ }^{21}$ and amongst foreign office lawyers it would seem that the quay has turned the ship around by now: Foreign Office lawyers are increasingly critical of the use of ostensibly non-legally binding instruments, precisely because they can no longer control what other ministries are up to. ${ }^{22}$

When the boundaries between law and non-law become porous, and when many different authorities (different ministries, but also water boards and other administrative units, and cities) and even private actors can be said to somehow be involved in international law, the concept of a "national practice" becomes unwieldy, and reporting on it will always be incomplete and vulnerable to criticism about what ought to have been included or excluded.

\section{Dispensability}

During my formative years, academic research was both easy to find and hard to find. It was easy in the sense that a decent library had an x-amount of journal and yearbook subscriptions, and if its subscriptions covered a reasonable amount of generalist publications as well as specialist outlets on particular topics, one could always find something to work with: the flow of possibly relevant earlier work was manageable, and while one would know that there existed other journals and other yearbooks as well, in addition to those held by the local university library, it somehow only rarely felt really, really important to have a look at some piece in some obscure or unavailable periodical. And of course, doing my graduate and doctoral work in the Netherlands, I was extremely fortunate: if it actually seemed, however rarely, that a particular article in a particular journal was indispensable yet unavailable in the Amsterdam international law library, I could simply take the train to The Hague and visit the Peace Palace Library, which had a far larger collection of journals - something far less easy to do when one is based in, say, Turku, or Palermo - let alone outside Europe. And while I did so occasionally, I did not do so regularly; it only

\footnotetext{
${ }^{20}$ For an excellent anthropological account of one of the Nordic foreign ministries (though not focusing on the international law section), see Iver B. Neumann, At Home with the Diplomats: Inside a European Foreign Ministry (Ithaca NY: Cornell University Press, 2012).

${ }^{21}$ Anthony Aust, 'The Theory and Practice of Informal International Agreements', (1986) 35 International and Comparative Law Quarterly, 787-812.

22 Jan Klabbers, 'Governance by Academics: The Invention of Memoranda of Understanding', (2020) 80 Zeitschrift für ausländisches öffentliches Recht und Völkerrecht (forthcoming).
} 
happened if I had become convinced that this particular piece, unavailable in Amsterdam, was absolutely indispensable. And that impression would usually only emerge upon seeing it referred to or discussed in works by others. In this sense, the process was rather self-referential: an article became important because others referred to it, and I sometimes had to reach the conclusion (upon finally reading it) that actually it was not very good, or not very helpful - and that was educational in its own right: one should not always trust what the herd says.

None of this is applicable anymore, except perhaps for that conclusion: articles become important because others say they are important. But it is no longer so difficult to find things: I have electronic access to journals that I never knew existed, that I have never held in my hands, that I have never seen in hard copy. And the number of journals has multiplied over the last three decades or so. I do not remember from my student days that there were student-run journals in the Netherlands; nowadays, without checking, I can identify at least a handful, with law faculties in Utrecht, Rotterdam, Tilburg, Groningen, and Free University of Amsterdam all publishing their own law review, however irregularly perhaps. And while I am writing this (quite literally), a leading publishing house announces the launch of a new law journal dedicated to international human rights law: the European Convention on Human Rights Law Review. ${ }^{23}$ This adds to a landscape that already comprises a number of specialized human rights journals, and where the generalist journals too publish articles on human rights developments with some regularity. The promise is clear: no stone will be left unturned, no practice will be left unstudied, no activity will be left unscrutinized.

Whether that promise will be met is a different issue altogether. It can safely be predicted that the new journal will comment on case-law developments, and will comment on highly publicized public statements by some of the parties to the European Convention. It might publish socio-legal work on the composition of the Court, and whether or not the nationality of a judge is reflected in his or her voting behaviour. It may even come to publish work that is critical of the European Court, a critique of a particular decision or set of decisions. But it is unlikely to publish much that is not already done elsewhere, and is done just as competently elsewhere, in the Human Rights Quarterly, or in the variety of journals with near-identical titles: the Human Rights Review, the Human Rights Law Review, or the International Human Rights Law Review, or any other of the many journals already dedicated to human rights law. This is precisely the reason why three decades ago, the relatively limited supply of research work available to me did not seem to affect my work too much: much of what is published tends to be repetitive, both in terms of topic and in terms of analysis. The newly announced journals promises to add yet more of the same, but is unlikely to do much more. And indeed, it is unclear what that "more" could even be.

Given the increase in the number of journals, and the emergence of blogs (where self-aware authors can - and do - serialize or advertise their own articles) and tweets, the yearbook is bound to take on a different role. If in the 1920s and 1930s it was still thinkable to publish a case-

\footnotetext{
${ }^{23}$ https://brill.com/view/journals/eclr/eclr-overview.xml (visited 28 October 2019).
} 
comment in a yearbook (a case in point being the analysis, under pseudonym, of the Oscar Chinn case in the British Yearbook), ${ }^{24}$ such is no longer thinkable: time just moves too quickly. Still, serving the global community, there is a role for yearbooks as filtering devices. This is not unlike what they used to do (filtering judicial practice, filtering state practice, filtering literature), and it is clear that the demand for such work has only increased. The marketplace of international legal scholarship (and other academic disciplines, for that matter) is bombarded by Oxford Handbooks, Cambridge Companions, Research Handbooks, Very Short Introductions, Advanced Introductions, and much, much else besides. Oxford University Press publishes bibliographies online; publishes International law in Domestic Courts on-line, publishes an International Organizations database, as well as the large Max Planck Encyclopedia of Public International Law, soon to be accompanied by a Max Planck Encyclopedia of Comparative Constitutional Law.

Cambridge University Press is less active here (it may have missed the boat), but still publishes the International Law Reports. What these publications have in common is their filtering function: they teach novice and experienced scholar alike what is relevant and what is not; what is worth looking at and what is not.

Moreover, the role of both fostering and manifesting a particular domestic community of international lawyers remains of some relevance. If often producing a yearbook is the work of obsessive individuals, ${ }^{25}$ it could also be produced by a dedicated national institution, with the T.M.C. Asser Institute in the Netherlands, so wonderfully re-invigorated in recent years, as an inspirational model. The Chinese have already understood this of course, with the Chinese Journal of International Law doing an excellent job as a forum for official policy, and nurturing and reflecting a Chinese approach to international law. ${ }^{26}$ In a world where it is no longer assumed that international law is actually international, ${ }^{27}$ a yearbook might be the ideal venue where a wellfunded research community (whether institutionalized or not) could concentrate, expand and use its epistemic authority. And epistemic authority is quite possibly the most relevant form of authority to begin with.

Sadly though, the current fascination for rankings, scientific breakthroughs, and paradigm shifts (as if...), entails that the yearbook is bound to remain a retrograde venue, tolerated more than stimulated. In terms of the quality of the research published in most yearbooks this may be justifiable, but as so often, the measurable tells only half the story. I would have been a different, and quite possibly considerably worse, international law academic without the yearbooks; they perform an introductory role to the discipline in ways that other publications will find difficult to

\footnotetext{
${ }^{24} \mathrm{O}$ (a pseudonym), 'The Chinn Case', (1935) 16 British Yearbook of International Law, 612-164. I had somehow surmised that "O" was a pseudonym for Hersch Lauterpacht, but this is probably untenable: he published other short case notes as "H.L."

${ }^{25}$ The Czech Yearbook of International Law is inextricably linked to Alexander J. Belohlávek and Nadezda Rozehnalova, e.g., as is the Czech (and Central European) Yearbook of Arbitration. Intriguingly, there is a competing publication, the Czech Yearbook of Public and Private International Law, just as inextricably linked to Pavel Sturma.

${ }^{26}$ The Chinese reservoirs are so large that enough material can be generated to fill a journal four times per year, as is the case with the American Journal of International Law, which has done much the same since 1906. There is no need for a yearbook. Incidentally, the Chinese Journal also seems happy to serve as an outlet for none-too-subtle pieces highly critical of the US government: see Stefan Talmon, 'The United States under President trump: Gravedigger of International Law', (2019) 18 Chinese Journal of International Law, 645-668.

${ }^{27}$ Anthea Roberts, Is International Law International? (Oxford University Press, 2017).
} 
emulate. My rites of passage came from yearbooks, more so than from more heralded publications. Working with the state practice section of the Netherlands Yearbook or the British Yearbook taught me more than the average Google search can teach, and in ways that can hardly be replaced by reading an extra textbook or two or an additional slew of journal articles. The great Michael Oakeshott once suggested in full Aristotelian mode that education is best done one-onone, with the pupil sitting beside the master and learning by doing: “... practical knowledge can neither be taught nor learned, but only imparted and acquired. It exists only in practice ... [and] ... can be acquired only by continuous contact with one who is perpetually practicing it." ${ }^{28}$ That is probably no longer feasible, but yearbooks used to be a decent substitute, helping to initiate the novice international lawyer to become a more competent international lawyer, and doing so by opening up the practice of states which, on some conceptions, remains the basis of international law. ${ }^{29}$

There are obvious drawbacks of course: since any selection of materials is selective, a comprehensive overview is always filtered by the gate-keeper, and by making state practice available, states could exercise influence over the formation of new rules and the proper interpretation of others in ways that were not available to states too poor or disorganized to publish their state practice. As manifestations of epistemic authority, there is good reason to be suspicious of the yearbook, but this too is a lesson that can be learned by actually using the yearbook.

\footnotetext{
${ }^{28}$ Michael Oakeshott, 'Rationalism in Politics', reproduced in Michael Oakeshott, Rationalism in Politics and Other Essays (London: Methuen, 1962), 1-36, at 11.

29 Jan Klabbers, 'On Epistemic Universalism and the Melancholy of International Law', 82018) 29 European Journal of International Law, 1057-1069.
} 